ingly delicate plant, 5 to 6 inches high grows in pine woods. Each spring it sprouts from a nearly globose corm, hence the name "bulbosa." The word Calypso is derived from the Greek Goddess Calypso, who was the Goddess of Eternal Life and Beauty. The plant bears a single leaf which has a rounded-ovate blade, acute at the apex and rounded at the base. The flower is pink; the petals and sepals are similar and each bears three purple lines. The lip is large and has a tuft of yellow hairs.

In the area I found two species belonging to the coral-root genus. This group of orchids contains saprophytes. They do not possess chlorophyll but feed entirely on dead and decaying organic matter. The plants are leafless and have a scaly, colored stem arising from thick coralloid roots. The flowers are in terminal spikes with nearly equal sepals, the lateral ones united with the foot of the column, forming a short spur. In this genus, Corallorhiza, I found two species, the large coral-root and the striped coral-root, and what I believe to be an additional variety-the yellow form of the striped coral-root.

Corallorhiza maculata Raf., the large coral-root, grows quite tall, measuring up to 20 inches in height. The stem is purple and covered with scales. The 10 to 30 flowers are racemous, brownish-purple with a white lip, the latter spotted and lined with red-purple markings.

Corallorhiza striata Lindl., the striped coral-root, is also a tall growing species with a stout stem. The flowers, also racemous and numbering up to 25, are purple with dark veins. These wax-like plants were found in scattered locations in aspen woods throughout the area. The yel- low form of Corallorhiza striata (C. ochroleuca Rydb.) was found only once in a moist, shady part of an aspen grove. This species has been collected at Elkwater Lake, Alberta, by R. G. H. Cormack. The flowers are light yellow and unspotted and have a prominent mid-vein on the sepals and petals.

From the genus Habenaria, I found H. ob usata (Pursh) Richardson. This small northern bog orchid was found in a boggy spot in a spruce forest. It is a slender plant, about 10 inches in height with no stem leaves. There is one solitary obovate leaf at the base of the plant. The loosely flowered spike bears small greenish flowers with slightly curved spurs.

The other species in the genus Habenaria that I found was $H$. bracteata (Willd.) R. Br., the long-bracted orchid. As the name indicates the lower bracts are longer than the greenish flowers. These bracts are very conspicuous. The lip is threetoothed at the apex, the middle tooth being the smallest. It grows in moist meadows and open woods. I found this one in such a meadow near the lower lake at the park.

Finally there was the delicate round-leaved orchid, Orchis rotundifolia Pursh. This plant is about 10 inches high. It carries about six rose colored flowers in its terminal spike. The lip is white with small purple spots. This prominent petal is threelobed with the large middle lobe notched at the apex. The spur is slender and curved. Near the base of the plant is a solitary leaf, orbicular or oval in form. It grows in cold, damp woods and I found it in a deep spruce coulee which was quite moist in places because of numerous small springs.

\title{
What Is Tuckahoe?
}

\section{By Joyce Dew, Saskatchewan Museum of Natural History}

"Tuckahoe" is of special interest to the biologist, ethnologist, and to the farmer who turns it out of the soil while doing fresh breaking. Through usage the term has come to be applied to a variety of underground growths. One of these, Polyporous tuberaster, described by T. C. Van- terpool in Vol. X, No. 1 (1952) of the Blue Jay is the sclerotium or resting stage of a fungus. This sclerotium is described as being spherical to oval and occasionally slightly flattened, of a hard rubbery consistency when fresh, but of stone-like hardness when dried. The specimens 
examined by Vanterpool were found in the Aspen Grove or Parkland belt of the province, or from a belt parallel to and northeast of a rough line running from Moosomin in the southeast, through Touchwood and Radisson to Senlac in the northwest of the province. Fruiting bodies appear on these sclerotia from the end of June to the end of July. If a fresh specimen is taken and planted several inches below the soil it may produce a mushroom-like fruiting body. This fruiting body, as the genus name Polyporous suggests, has pores rather than gills on the underside.

In the Canadian Journal of Botany, 29; 147-157. 1951, T. C. Vanterpool and Ruth Macrae give details of culture tests which established that the fungus was the same species as the one long known from Italy.

The name tuckahoe also applies to a fungus growth in southeastern United States where it is called southern tuckahoe or Indian bread. The southern tuckahoe is quite different from the fungus of Western Canada but the name "Indian Bread" has been applied to both of them. Vanterpool states that there is no record of the sclerotium of Polyporous tuberaster having been eaten, being much too tough, but the Indians may have used it for poulticing and for rheumatism.

The Saskatchewan Museum of Natural History has received samples of tuckahoe from the following areas: Dysart, Neudorf, Bulyea, Wolseley, Summerberry, Round Lake, Regina, Whitewood, Abernethy and Carrot River and 40 miles north of Meadow Lake. The exterior surfaces of some of these specimens are much more irregular than those reported by Vanterpool.

Tuckahoe is a name which has been applied as well to certain edible rootstocks of flowering plants. The word apparently originated in eastern Canada referring to underground roots. Early explorers listed it among the foods eaten by the Indians. The confusion which exists here is summed up by John R. Swanton in the Smithsonian Institution's Bulletin 137, "The Indians of the Southeastern United States," when he states: "Generally speaking, the identity of the roots used as a food is in greater doubt than any other vegetable or animal product mentioned by early writers." He is of the opinion that a food called Coscushaw by the Spaniards and used by the Indians to make bread ". . is called in Virginia tuckahoe, and in the present instance the name probably refers to the golden club or floating arum (Orontium aquaticum) though the name was also applied to the roots of the Virginia wakerobin (Peltandra virginica) or "poison arum," to the Apios tuberosa and to tuberlike objects due to the disintegration of the roots of trees (mainly conifers). Farther south on the coast of the Carolinas, it was known as "wampee ..." The juice of the plant referred to as Virginia tuckahoe was poison and had to be extracted from the root before the bread was made. The roots were either sliced and dried in the sun or by the fire, and then were pounded into flour which made good bread. Green roats as well were pounded, then left by the fire to dry. The bread made from it was reported to taste very good.

It would appear that the word "tuckahoe" was first applied to certain underground growths listed among foods used by the Indians. In present day usage it is frequently applied to any dark brown, more or less spherical, hard, vegetable material found underground. This object when first unearthed is sometimes mistaken for pemmican. The hard, dry, wrinkled, leathery appearance of the outside and the composite appearance of the cross-section have led to the assumption that it could se dried buffalo meat in a leather storage bag. Pemmican, however, would soon disintegrate due to bacterial action if it were left for long in the moist ground. In conclusion, I find it much easier to say that what "tuckahoe" isn't than to define what tuckohoe is.

Several specimens of "tuckahoe" are at present on display at the Saskatchewan Museum of Natural History. 